Гордана Штасни

Филозофски факултет Универзитета у Новом Саду

gordanastasni@yahoo.com
УДК $811.163 .41 ` 367.622 .16$

Оригиналан научни рад

\title{
НЕРЕГИСТРОВАНЕ ГЛАГОЛСКЕ ИМЕНИЦЕ У СРПСКОМ ЈЕЗИКУ ${ }^{1}$
}

У раду се испитују семантичко-деривационе карактеристике глаголских именица са суфиксом -ње и њихов статус и перспектива у лексичком систему српског језика. Сагледане су морфолошко-семантичке карактеристике глагола које имају индуктивну односно рестриктивну функцију у деривацији именица суфиксом -юе, као и лексичка семантика деривираних супстантива. Истраживање је спроведено на корпусу Обратног речника нових и незабележених речи (2003) Ђорђа Оташевића.

Кључне речи: деривација, глаголске именице, суфикс -ње.

\section{1. УВОД}

Глаголске именице представљају веома плодну именичку врсту у лексичком систему српског језика, а њихова деривација најпродуктивнија је суфиксом -ње..$^{2}$ Оне су дуалистичке природе, будући да имају категоријална обележја на основу којих се сврставају у морфолошку класу именица, као и својства која их у семантичком и синтаксичком смислу чине блиским глаголима.

На плану значења доминантно је њихово опште својство „да значе вршење радњи које означавају глаголи од којих су изведене или са којима имају исти корен” (Mrazović 2009: 230). То значи да се глаголским именицама у потпуности чува концептуална вредност мотивног глагола само у другачијој, именичкој форми. ${ }^{3}$ Глаголске именице мотивисане имперфективним глаголима

1 Рад је настао у оквиру пројекта Стандардни српски језик: синтаксичка, семантичка и прагматичка истраживања (178004), који финансира Министарство просвете и науке Републике Србије.

2 М. Стевановић наводи да се глаголске именице најчешће изводе суфиксом -ње (1964: 527).

3 Клајн сматра да именице на -ње „нису девербалне (девербативне) именице, као оне с другим суфиксима, него су глаголске именице - глаголски облик у именичкој функцији” 
углавном значе процес, трајање (читати - читање), ретко резултативност (печење 'печено месо' треба разликовати од облика печење обоје од глагола пећu).

1.1. За деривацију глаголских именица важан је аспект мотивног глагола. Овај проблем је одавно уочио А. Белић (1933: 262-268) и истакао да се глаголске именице углавном граде од имперфективних глагола, веома ретко од перфективних, а разлоге проналази у значењу тих образовања. Ј. Вуковић, такође, утврђује услове за деривацију глаголских именица од свршених глагола и открива их у њиховој семантичкој структури јер „ако свршени глагол развија и које друго значење, поред основног, онда се ствара могућност за образовање по које глаголске именице ... или ... ако се основни глагол изгубио или је глаголска основа изменила значење у сложеном глаголу" (1950: 164-165). ${ }^{4}$

1.2. Узроци се могу пронаћи и у семантичким обележјима имперфективности односно перфективности. „Тіріс̌nu perfektivnost glagola označava nedeljiva celina sa jasno označenim rezultatom ili ostvarenim ciljem koji obuhvata sve delove glagolske situacije, dakle, radnju ili zbivanje u potpunosti izvršene, ali bez naglašavanja trajanja. Imperfektivni glagoli izražavaju radnju koja je deljiva, ona je samo deo glagolske situacije, celine, jer joj nedostaje završni segment. Njima se iskazuje proces, zbivanje, radnja i stanje u njihovom toku, u trajanju ili ponavljanju, tako da se radnja ne može shvatiti kao celina. Na primer: Naši prijatelji su sagradili novu kuću. pf. - ostvaren cilj, celina; Naši prijatelji su (godinama) gradili kuću. - impf. - proces, razvoj, deo celine" (Mrazović 2009: 80-81).

Издвајамо важне семантичке компонете садржане у појмовној вредности перфективности односно имперфективности које имају рестриктивну односно индуктивну функцију у деривацији глаголских именица: финитност односно нефинитност; целовитост односно фрагментарност или процесуалност глаголске радње. Још једно својство глагола сматрамо релевантним за рестрикцију творбе глаголских именица - теличност. Перфективни глаголи су по правилу телични и подразумевају циљ (Novakov 2009: 46).

Дакле, индуктивну улогу имају следеће компоненте из значењског

(2003: 169).

4 Клајн наводи да се „именице од свршених глагола не изводе системски, по граматичком

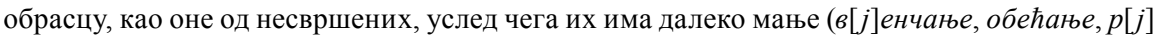
ешење, рођење, спасење) (2003: 172). 
домена аспектуалности: нефинитност и процесуалност глаголске радње из којих произилазе својства хабитуалности и трајности са обележјем прогресивности ( читати $\rightarrow$ читање, писати $\rightarrow$ писање, пливати $\rightarrow$ пливање).

T. Трезнер је указао на нека ограничења у деривацији именица на -ње од перфективних глагола, укључивши не само граматичке већ и семантичкодеривационе параметре, као што је, у првом реду, утицај деривационог статуса изведених речи. Тако перфективни глаголи који су мотивисани неком именском речју творе глаголске именице (оздравити $\rightarrow$ оздрављење, одушевити $\rightarrow$ одушевљење, одликовати $\rightarrow$ одликовање), док они са глаголском основом не творе (написати, прочитати, погледати) ${ }^{5}$.

1.3. Поред перфективности, рестриктивно обележје за деривацију глаголских именица јесте интранзитивност. А. Терзић наводи да су се од „свих прелазних глагола несвршеног вида увек могле, и данас се могу, изводити глаголске именице" (1964: 47). Наиме, објекатском допуном транзитивних глагола денотира се резултат глаголског процеса, укључује се, дакле, обележје резултативности глаголске радње (брисати - брисање, ложити - ложење, nецати -nецање). Дакле, глаголске именице ретко су мотивисане перфективним интранзитивним глаголима, и још ређе имперфективним интранзитивним глаголима (летње, седеґе, бдење $)^{6}$. Бабић наводи да су много већа ограничења творбе глаголских именица на -ње од свршених глагола и додаје да се ,imenice tvore prvenstveno od prelaznih glagola, tj. od onih koji imaju pridjev trpni, rijetko od drugih" (1986: 128).

\section{2. КОРПУС}

Са намером да укажемо на иновативне моменте у деривацији

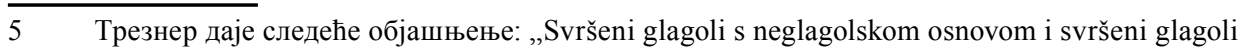
s glagolskom i izvornom osnovom nemaju istovjetno polazište s obzirom na njihovu tvorbu. Prvi u samoj osnovi imaju imenske značajke, ..., a drugi su glagoli već u osnovi obilježeni glagolski, naime, glagolski vid, jedna od najbitnijih glagolskih značajki, dan je u osnovi. Oduševiti i napisati svršeni su glagoli; prvi glagol ima glagolski vid prenesen, koji zapravo ne proistječe iz osnove riječi, a glagol napisati obilježen je primarnim glagolskim vidom (Trezner 1970: 52).

6 Творбу глаголских именица од имперфективних интранзитивних глагола старији граматичари обично су тумачили на примеру именице летење и указали на то да глаголска именица не мора бити мотивисана тразитивним глаголом и имати глаголским придев трпни у основи, што се „нарочито лепо види код глагола на -ети, који, као непрелазни, махом и немају придева трпног, али могу имати глаголску именицу” (Ђорђић 1932: 174). На истим примерима (летење и седење) и А. Белић тумачи проблем са дијахроног (као и Ђорђић), али и нормативистичког становишта (1956: 217-222). 
глаголских именица у систему српског језика спроведена је семантичкодеривациона анализа на примерима ексцерпираним из Обратног речника нових и незабележених речи (2003) Ђорђа Оташевића. Определили смо се за овај тип речника будући да су у њему забележени новији примери и то у веома великом броју. Од укупно 11332 речи глаголских именица на -ље има 414. Збележене лексеме различитог су деривационог типа: суфиксираних изведеница има 155 , префиксала 127, сложеница 98 и 27 полусложеница.

Међутим, лексеме обухваћене Оташевићевим речником нису дефинисане нити се наводи извор из којег су ексцерпиране, тако да смо потврду за значења наведена у анализи одабраних јединица проналазили у електронским изворима.

Анализом су обухваћене именице деривиране суфиксом -ње од глагола на -ати (и сложеним варијантама овога суфикса). ${ }^{7}$ Овим суфиксом се граде глаголске именице, глаголски облици у именичкој функцији, дакле, деривати граматичке природе. Важно је, међутим, у семантичко-деривационом смислу са којим се глаголским основама комбинује овај суфикс и који су мотивни глаголи лексикализовани, а који су само потенцијални, као и значења деривираних именица. У раду су непотврђени, реконструисани, мотивни глаголи означени звездицом (*).

Када је творба глаголске именице (која је нерегистрована у речницима) мотивисана лексикализованим имперфективним глаголом, такав дериват нећемо сматрати иновативним, а таквих је примера у Оташевићевом регистру у већем броју (лобирање, асочирање, скенирање, позичионирање, клонирање, кадрирање, сервисирање, индексирање, романсирање, ииклусирање итд.). По правилу је реч о дериватима који су мотивисани лексемама страног порекла и који се деривирају по моделу: 0 именица $\rightarrow 1$ глагол $\rightarrow 2$ глаголска именица ( 1 лоби $\rightarrow 2$ лобирати $\rightarrow$ лобирање). Велики број ових именица има статус термина.

7 У коментару Терзићевог рада (Структурно-семантичке одлике глаголских именица творбеног типа -ние, -ение у руском и -ње, -ће у српскохрватском језику (1969). Анали Филолошког факултета. IX. 27-93) Клајн истиче да наилазимо на велике тешкоће ако покушамо да именице на -ње синхронијски анализирамо без икаквог позивања на трпни придев. „Испоставља се да морамо разликовати два суфикса, -ње за глаголе на -ати (чита-ње) и неколико њих на -ети (вре-ње, презре-ње), -ење за остале (гор-ење, једр-ење, трес-еље, буч-еље итд.). При томе се први суфикс додаје на инфинитивну основу, а други на презентску без крајњег вокала" (2003: 168). 
У раду се, такође, нећемо посебно бавити дериватима који имају у савременом језику алтернативне облике на -ащија, нпр. хомогенизирање : хомогенизачија, идеологизирање : идеологизација, парцелизирање : парцелизација и сл. будући да је реч о творбеним дублетима са донекле устаљеном употребом.

\section{3. МОТИВНИ ГЛАГОЛИ СА ИМЕНИЦОМ У ТВОРБЕНОЈ ОСНОВИ}

3.1. Системска је појава да суфикс -ати у комбинацији са именичком основом деривира глаголе имперфективног вида веома различитог значења. Опште значење глагола који су настали по овом творбеном моделу могло би се према Бабићевом тумачењу интерпретирати као „djelovanje u vezi sa značenjem osnovne imenice, npr. komadati $\rightarrow$ odvajati na komade, sunčati se $\rightarrow$ izlagati se suncu, vrstati $\rightarrow$ stavljati u vrste (1986: 449). У нашем случају нелексикализовани глаголи мотивисани су претежно именицама страног порекла са месним или конкретним предметним значењем. Обичнијим образовањима могу се сматрати глаголи мотивисани називима предмета ${ }^{8}$, док је мотивација именицама са месним значењем неуобичајена, а значење глаголског деривата и његове именице не одражава само концепт глаголске радње, већ је и квалификује (нпр. чаршијати 'проводити слободно време у чаршији' - чаршијағе). ${ }^{9}$

8 „Glagoli od imenica koje znače predmete veoma često označuju obavljanje radnje sredstvom označenim imenicom u glagolskoj osnovi prema preoblici i + ati $\rightarrow$ glagol + instr. im (batinati $\rightarrow$ udarati batinom)" (Babić 1986: 449).

9 Још једном скрећемо пажњу на то да лексеме наведене у Обратном речнику нових и незабележених речи (2003) Ђорђа Оташевића нису дефинисане, нити се наводи извор, те нам стога није могуће да поуздано и прецизно утврдимо њихов трансформациони модел. 


\begin{tabular}{|c|c|c|c|c|}
\hline $\begin{array}{l}\text { Творбени } \\
\text { модел } \\
\text { мотивног }\end{array}$ & $\begin{array}{l}\text { Мотивна } \\
\text { именица }\end{array}$ & $\begin{array}{l}\text { Деривирани } \\
\text { глагол } * 10\end{array}$ & $\begin{array}{l}\text { Трансформациони } \\
\text { модел }^{11}\end{array}$ & $\begin{array}{l}\text { Глаголска именица } \\
(\text { Го + -ње })\end{array}$ \\
\hline \multirow[b]{8}{*}{ Ио + -ати } & котураљка & котураљк-ати & ВОЗИТИ се $\mathrm{X}_{\text {инстр. }}$ & котураљкање ${ }^{12}$ \\
\hline & пендрек & пендрек-ати & ударати X инстр. & пендрекање \\
\hline & перла & перл-ати & низати X & перлање \\
\hline & сабља & сабљ-ати & борити се X & сабљање \\
\hline & чакија & чакиј-ати & баратати X & чакијање \\
\hline & спреј & спреј-ати & прскати X & спрејање \\
\hline & чаршија & чаршиј-ати ${ }^{14}$ & $\begin{array}{l}\text { проводити слободно } \\
\text { време у X }\end{array}$ & чаршијање \\
\hline & шунгла & џунгл-ати & $\begin{array}{l}\text { понашати се као у } \mathrm{X}^{15} \\
\text { пробијати се кроз X }\end{array}$ & џунглање \\
\hline
\end{tabular}

3.1.1. Суфикс -ати јавиће се и у префиксално-суфиксалној твореници о-човеч-ати, која ће се наћи у основи мотивног глагола очовечавати, а он у основи супстантива очовечава-юе.

\section{2. У нашем узорку суфикс -авати јавља се у префиксално-суфиксалним} твореницама са именичком творбеном основом, што није уобичајена појава у деривационом систему. Осим тога, за речи наведене у табели нисмо нашили потврде у електронским изворима.

\begin{tabular}{|l|l|l|}
\hline \multirow{5}{*}{ префикс + Ио + -авати } & о-спокој-авати & оспокојавање \\
\cline { 2 - 3 } & по-простор-авати & попросторавање \\
\cline { 2 - 3 } & раз-вер-авати & разверавање \\
\cline { 2 - 3 } & рас-кулуч-авати & раскулучавање \\
\hline & раш-чаробњ-авати & рашчаробњавање \\
\hline
\end{tabular}

Имперфективни глаголи понорвеж-авати и расрбљ-авати могу се сматрати дериватима који су мотивисани перфективним облицима по-норвеж-

10 У навођењу реконструисаних мотивних глагола биће занемарене могуће реализације глагола са морфемом се. Повратни глаголи регуларно учествују у творби глаголских именица, тако да немају рестриктивну улогу због које би се на њих морала посебно скренути пажња.

11 Трансформациони модел углавном је изведен према аналогији са постојећим и продуктивним деривационим моделима или према потврди у електронским изворима.

12 Глаголска именица котураљкање припада деривационом низу: 0 котур $\rightarrow 1$ котур-аљка $\rightarrow 2$ котураљк-ати* $\rightarrow 3$ котураљка-ње*.

13 Облик сабљање настао је према уобичајеном моделу мачевање.

14 У електронским изворима наишли смо на облик прочаршијати (се) са значењем 'провести се, забавити се у граду'(Милица Ђорђевић: smoderc.fil.bg.ac.rs).

15 Не знамо да ли је глаголски дериват мотивисан основним или фигуративним значењем лексеме иунгла 'несређено стање, неред'. 
ити и ра-срб-ити а њихове глаголске именице понорвежава-ње и расрбљаваюе представљају деривате даљег степена. Уобичајена је творба глаголских деривата који су мотивисани етницима $(\mathrm{X})$ са значењем 'учинити да неко постане X', нпр. посрбити (се) / посрбљавати (се) 'постати Србин'. ${ }^{16}$ Суфикс -авати уноси обележје итеративности, а укупно значење деривата зависи семантичког садржаја мотивне именице и употребљеног префикса.

3.3. Суфикс -овати најчешће се комбинује са именичким основама градећи имперфективне или двовидске глаголе. Клајн наводи да је „међу тим глаголима повећа група оних од именица са значењем људског бића, где глагол означава обављање професије” (2003: 350), као и у нашем узорку. Он издваја и групу деривата који значе радњу или активност (пословати, службовати, свадбовати, пировати, доручковати и др.), док се остале тешко класификују с обзирм на најразличитије конкретне или апстрактне односе према мотивној именици (бичевати, каменовати, прстеновати, мачевати се, именовати, руковати се, становати, логоровати...) (Клајн 2003: 350).

\begin{tabular}{|c|c|c|c|c|}
\hline $\begin{array}{l}\text { Творбени } \\
\text { модел } \\
\text { мотивног } \\
\text { глагола }\end{array}$ & $\begin{array}{l}\text { Мотивна } \\
\text { именица }\end{array}$ & \begin{tabular}{|l} 
Деривирани \\
глагол*
\end{tabular} & $\begin{array}{l}\text { Трансформациони } \\
\text { модел }\end{array}$ & Глаголска именица \\
\hline \multirow{10}{*}{ Ио + -овати } & потпредседник & $\begin{array}{l}\text { потпредседник- } \\
\text { овати }\end{array}$ & $\begin{array}{l}\text { обављати дужност } \\
\mathrm{X}\end{array}$ & потпредседниковање \\
\hline & управник & управник-овати & $\begin{array}{l}\text { обављати дужност } \\
\mathrm{X}\end{array}$ & управниковање \\
\hline & премијер & премијер-овати & $\begin{array}{l}\text { обављати дужност } \\
\mathrm{X}\end{array}$ & премијеровање \\
\hline & гастарбајтер & $\begin{array}{l}\text { гастарбајт- } \\
\text { овати }^{17}\end{array}$ & радити као X & гастарбајтовање \\
\hline & прах & прах-овати & посипати $\mathrm{X}_{\text {инстр. }}$ & праховање \\
\hline & песма & песм-овати ${ }^{18}$ & $\begin{array}{l}\text { стварати/створити } \\
\mathrm{X} \\
\text { певати/отпевати X } \\
\end{array}$ & песмовање \\
\hline & пламен & пламен-овати ${ }^{19}$ & третирати $X_{\text {инстр. }}$ & пламеновање \\
\hline & мрак & мрак-овати ${ }^{20}$ & $\begin{array}{l}\text { деловати мрачним } \\
\text { силама на кога }\end{array}$ & мраковање \\
\hline & бостан & бостан-овати & садити X & бостановање \\
\hline & узорак & узорковати & узети/узимати X & узорковање \\
\hline
\end{tabular}

16 Srpski kulturni centar Sveti Sava sutra organizuje promociju knjige Koste Čavoškog pod nazivom „Rasrbljavanje”(http://www.yueco.rs/vest/kultura/rasrbljavanje). 
Деривати забележени у нашем извору клоновање, јауковање неуобичајени су у односу на облике клонирање и јаукање управо због мотивних глагола изведених суфиксом -овати (клоновати) према -ирати (клонирати) и -овати (јауковати) према -ати (јаукати).

Необичност деривата, како глагола тако и именице, може бити условљена и семантичким садржајем мотивних именица. Тако, на пример, семантичкодеривациона гнезда мотивисана фитонимима по правилу не садрже глаголе (бостановати). ${ }^{21}$

У извору је и глаголска именица суседовање. Њен мотивни глагол суседовати у РСЈ има значење 'налазити се у суседству, у близини некога или нечега'. Трансформациони модел може се креирати и према значењу лексеме пријатељевати 'бити с ким пријатељ' и изразити се општом формулом ‘бити с ким X'. Глаголска именица није забележена у РСЈ, што је и очекивано с обзиром на концепцију самог речника, а електронски извори показују да је њена употреба ипак новијег датума. ${ }^{22}$

Такође није продуктивна комбинација суфикса -овати са придевима.

17 У основи деривата гастарбајтовати налази се скраћена именичка основа.

18 У електронским изворима потврђена су два значења глаголске именице песмовање. Прво: ,... svesti o tome šta treba da budu figure mitske i kulturalne opstojnosti savremenog srpskog pesmovanja..." (http://www.hereticus.org/arhiva/pesnistvo-kulture.html); Namera ovog rada nikako nije da podastre utisak kako se oko vrednosti Karanovićevog pesmovanja, navodno, lome koplja. (http://principova.wordpress.com), и друго: „Odgonetale se zagonetke, nazdravljalo, a onda je na red došlo pesmovanje, i svaki takmičar morao je da otpeva po pesmu." (http://forum. burek.com). Занимљив је податак да се у прегледаним електронским изворима ове лексема са првим значењем јавља само у текстовима Бошка Томашевића.

19 Глаголска именица припада штампарској терминологији: „Predmet koji se štampa ravnomernom brzinom prolazi ispod plamena i vrši se spaljivanje površinske strukture. Plamenovanje se vrši propan-butanom i vazduhom pod pritiskom koji se mešaju u gorioniku". (http://demo.tamponprint.co.rs/dodatna-oprema.html)

20 Лексема мраковање употребљена је у специфичном контексту: „ Čini se da postoji čitava menažerija sila i bića koja se neprekidno bave nekim oblikom mrakovanja, i koja nalaze neko zadovoljstvo u tome da drugima pomognu odabrati zlo i u njemu napredovati." (http://ponude. biz/knjige/y/yoga.pdf)

21 Семантичко-деривациона гнезда мотивисана фитонимом обично садрже релациони и посесивни придев, деминутив, аугментатив, именице са месним значењем, назив особа која гаји, продаје или воли да једе плодове те биљке и од њих изведени релациони и посесивни придеви, називи пића или јела припремљених од биљке или њених плодова.

22 На пример, „Sociolozi i socijalni psiholozi gnjave pitanjima o spremnosti za stupanje u brak, prijateljstvovanje ili susedovanje sa Romima, Albancima...” (http://www.danas.rs) 
Клајн наводи само неколико глагола од којих су обични лудовати, мудровати (2003: 351). У нашем материјалу регистровани су примери мушковағе (0 мушки $\rightarrow 1$ мушк-овати $\left.{ }^{*}\right)^{23}$ и плавовағе $(0$ плав $\rightarrow 1$ плав-овати $*)$, што се може сматрати аналошким образовањем према познатом глаголу 1 жутовати Ł жут (жути жутују, а црвени путују).

У релевантним изворима (Клајн 2003, Babić 1986) није описана комбинација суфикса -овати/-евати са основом збирног броја, и ова се комбинација може сматрати иновативном: 0 два $\rightarrow 1$ дв-оје $\rightarrow 2$ двој-евати* $\rightarrow 3$ двојева-юе; 0 два $\rightarrow 1$ дв-оје $\rightarrow$ 2 двој-ство $\rightarrow 3$ двојств-овати $* 4$ двојствова-юе.

3.3. Према Клајновом мишљењу, суфиксе односно „морфеме -изирати и -изовати најбоље је третирати као један суфикс, пошто су у великој већини случајева у слободној алтернацији. При томе је -изовати данас у Србији основни и чешћи облик” (2003: 357). На основу глаголских именица које су потврђене у електронским изворима стиче се пак утисак да је и у нашој језичкој пракси честа употеба глагола на -ирати, посебно у комбинацији са лексемама страног порекла и са статусом термина (историзирати, математизирати, психологизирати), што је њихова уобичајена и продуктивна комбинација. Изведени глаголи имају углавном фактитивно значење 'претворити у нешто', 'снабдети чиме', ‘дати особину X' (Клајн 2003: 358). У творби глагола углавном је заступљена редукована основа мотивних именица женског рода на -ија (истор-изовати, психијатр-изирати).

Клајн истиче да је суфикс -изовати продуктивнији у творби глагола који су мотивисани придевом, али „притом придевски суфикс редовно отпада, као у нормализовати $\leftarrow$ нормал(ан)" (2003: 359). Прецизна идентификација мотивне речи није увек могућа с обзиром на то да се у појединим случајевима може уочити паралелна мотивација, што ће се, нормално, одразити на степен деривата (0 апсурд $\rightarrow 1$ апсурд-изовати 'доводити до апсурда'; 1 апсурд(ан) $\rightarrow$ 2 апсурд-изовати 'чинити апсурдним').

23 Облик је могао настати по аналогији са глаголом момковати и глаголском именицом момковање иако је глагол момковати мотивисан именицом. 


\begin{tabular}{|c|c|c|c|c|}
\hline \begin{tabular}{|l} 
Творбени \\
модел мотивног \\
глагола
\end{tabular} & $\begin{array}{l}\text { Мотивни } \\
\text { придев }\end{array}$ & $\begin{array}{l}\text { Деривирани } \\
\text { глагол* }\end{array}$ & $\begin{array}{l}\text { Трансформациони } \\
\text { модел }\end{array}$ & $\begin{array}{l}\text { Глаголска } \\
\text { именица }\end{array}$ \\
\hline \multirow[t]{8}{*}{ Ио + -изовати } & паралела & паралел-изовати & $\begin{array}{l}\text { успостављати/ } \\
\text { успоставити X }\end{array}$ & паралелизовање \\
\hline & криминал & $\begin{array}{l}\text { криминал- } \\
\text { изовати }\end{array}$ & $\begin{array}{l}\text { давати/дати } \\
\text { особину X }\end{array}$ & криминализовање \\
\hline & историја & истор-изовати ${ }^{24}$ & $\begin{array}{l}\text { давати/дати } \\
\text { обележје X }\end{array}$ & историзовање \\
\hline & филозофија & $\begin{array}{l}\text { филозоф- } \\
\text { изовати }\end{array}$ & бавити се $\mathrm{X}_{\text {инстр. }}$ & филозофизовање \\
\hline & математика & математ-изовати & $\begin{array}{l}\text { давати/дати } \\
\text { обележје X }\end{array}$ & математизовање \\
\hline & еротика & ерот-изовати & $\begin{array}{l}\text { давати/дати } \\
\text { особину X }\end{array}$ & еротизовање \\
\hline & фрагмент & $\begin{array}{l}\text { фрагмент- } \\
\text { изовати }\end{array}$ & \begin{tabular}{|l|} 
давати/дати \\
особину X \\
\end{tabular} & фрагментизовање \\
\hline & субјект & субјект-изовати & $\begin{array}{l}\text { давати/дати } \\
\text { особину X }\end{array}$ & субјектизовање \\
\hline \multirow[t]{5}{*}{ Ио + -изирати } & психологија & $\begin{array}{l}\text { психолог- } \\
\text { изирати }\end{array}$ & $\begin{array}{l}\text { тумачити/ } \\
\text { протумачити } \\
\text { нешто из угла X }\end{array}$ & психологизирање \\
\hline & психијатрија & $\begin{array}{l}\text { психијатр- } \\
\text { изирати }\end{array}$ & $\begin{array}{l}\text { тумачити/ } \\
\text { протумачити } \\
\text { нешто из угла X }\end{array}$ & психијатризирање 27 \\
\hline & типологија & типолог-изирати & $\begin{array}{l}\text { сврставати/ } \\
\text { сврстати у типове }\end{array}$ & типологизирање \\
\hline & Ecej & есеј-изирати & $\begin{array}{l}\text { давати/дати } \\
\text { особину X } \\
\text { писати/написати у } \\
\text { духу X }\end{array}$ & есејизирање ${ }^{28}$ \\
\hline & техника & техн-изирати & $\begin{array}{l}\text { примењивати/ } \\
\text { применити X }\end{array}$ & технизирање \\
\hline
\end{tabular}

24 У електронским изворима појављује се облик историзирати у следећим контекстима: „Sintagme, predočene, i druge na ovom mjestu napomenute, imale su i imaju isključivo jedan cilj - zadržati, zacementirati i istorizirati bošnjačko-američko-amanpursku istinu o ratu u BiH." (http://www.poskok.info)

„Da bismo ovu hipotezu testirali i dokazali, nužno je prizvati u sećanje neka skorašnja kretanja, odnosno nju je potrebno , ,istorizirati” sa svrhom uvida u tragičan položaj srpskog naroda na početku novog milenijuma." (http://www.glas-javnosti.rs)

25 Према уобичајеном филозофирати.

26 У електронским изворима потврђена је глаголска именица математизирање „... kod Tesle ekskluzivno pojavljuje kao akt kreativne imaginacije čije matematiziranje vodi konačno do fizičkog modela." (http://www.nikolateslaclub.com), што се може трансформисати на следећи начин: исказивати/исказати на матаматички начин. Нисмо сигурни да је значење глагола математизирати и математизовати потпуно идентично.

27 Глаголска именица има употребну вредност што потврђују електронски извори: „Mislim da je to nepotrebno psihologiziranje ili psihijatriziranje situacije koja je vrlo konkretna i traži 
Глагол у основи именице сензибилизирање мотивисан је придевом сензибилизирати $\leftarrow$ сензибилан, што је у нашем узорку ређи случај.

3.4. Суфикс -ирати је најпродуктивнији глаголски суфикс страног порекла, и то у комбинацији са именичким основама страног порекла. Јавља се, међутим, и у хибридним изведеницама (са творбеном основом домаћег порекла), и оне имају обележје новог (податкирати). Деривирани глаголи претежно су двовидски. Клајн наводи да највећи део глагола на -ирати чине изведенице од именица, готово увек страног порекла, латинског и француског, уз покоји грецизам и италијанизам (докторирати, магистрирати, галопирати, луксузирати, кредитирати, базирати (се) и многи други) (Клајн 2003: 354). Ређе су хибридне сложенице (струкирати, лажирати, печатирати, живцирати), а још ређе оне мотивисане придевом (активирати, комплетирати, дуплирати, ажурирати) (Клајн 2003: 355)

\begin{tabular}{|c|c|c|c|}
\hline \multicolumn{4}{|c|}{ Ио + -ирати } \\
\hline Мотивна & Деривирани & Трансформациони & Глаголска именица \\
\hline именица & глагол* & модел & \\
\hline Амбијент & амбијент-ирати & створити/стварати X & амбијентирање \\
\hline Буржоазија & буржоаз-ирати (се) & $\begin{array}{l}\text { ширити утицај X } \\
\text { постајати/постати X }\end{array}$ & буржоазирање ${ }^{29}$ \\
\hline Десант & десант-ирати & спроводити/спровести X & десантирање \\
\hline Ecej & есејизирати & обрадити/обрађивати као X & есејизирање \\
\hline Инвалид & инвалид-ирати & $\begin{array}{l}\text { чинити/учинити да неко } \\
\text { постане X } \\
\text { представљати/ } \\
\text { представити кога као X }\end{array}$ & инвалидирање \\
\hline Индекс & индекс-ирати & $\begin{array}{l}\text { давати/дати нечему } \\
\text { вредност X }\end{array}$ & индексирање \\
\hline комбајн & комбајн-ирати & $\begin{array}{l}\text { обрадђивати/обрадити } \\
\text { земљу Хинстр. }\end{array}$ & комбајнирање \\
\hline Литванија & литван-ирати & ширити обележје X & литванирање \\
\hline Мејкап & мејкап-ирати & стављати/ставити X & мејкапирање \\
\hline
\end{tabular}

, rekla bih, idiosinkretički pristup, a ne definisanje opštih načela." (http://forum.b92.net/ topic/7908-pravo-na-smrt/)

28 Иако глагол и именица нису регистровани у речницима, глаголска именица се веома често користи у одређеним контекстима, нарочито у књижевној критици: „Ova knjiga, pored esejiziranja i izuzetno značajnog dokumentovanja performansne prakse sedamdesetih $\mathrm{u}$ Novom Sadu, donosi nam jednu zaista novu formu: drugarsku kritiku - dijalog...” (http://polja. eunet.rs/polja449/449-10.htm)

29 Са терминолошком вредношћу јавља се конструкција буржоазирање радничке класе. http://www.ppt2txt.com/r/z9b4dcae/ 


\begin{tabular}{|l|l|l|l|}
\hline Мимикрија & мимикр-ирати (се) & $\begin{array}{l}\text { примити/попримити } \\
\text { обележје X }\end{array}$ & мимикрирање \\
\hline Податак & податк-ирати & $\begin{array}{l}\text { давати/дати Х о некоме } \\
\text { или нечему }\end{array}$ & податкирање \\
\hline сауна $^{31}$ & саун-ирати се & $\begin{array}{l}\text { подвргавати се/ } \\
\text { подвргнути се третману } \\
\text { у X }\end{array}$ & саунирање \\
\hline стриптиз & стриптиз-ирати & изводити/извести X & стриптизирање \\
\hline Финеса & финес-ирати & правити/направити X & финесирање \\
\hline Циклус & циклус-ирати & $\begin{array}{l}\text { повезивати/повезати у X } \\
\text { спроводити/спровести X }\end{array}$ & циклусирање \\
\hline
\end{tabular}

Уобичајене су комбинације суфикса -ирати са именицама које имају предметно значење, али су неуобичајене комбинације са именицама које имају месно значење (саунирати), или са онима које денотирају човека (инвалидирати). Примећено је да поједине лексеме шире семантичку структуру и да су секундарне реализације са обележјем новог. На пример, лексема инвалидирати има значење правног термина 'поништити, оборити, обеснажити, лишити правног основа' (http://www.vokabular.org), али и наведено значење: „Kad sam počeo postavljati pitanja, počeli su me invalidirati obraćajući se mojim roditeljima da „kako su odgojili sina, nek se srame.” (http://www.artikcommunity. biz/).

3.5. Клајн наводи да је суфиксу -исати, иако је грчког порекла, место међу домаћим суфиксима (2003: 339). Комбинује се и са страним и са домаћим именичким основама (деформисати, информисати, евакуисати; угљенисати, тестерисати). Од именица са значењем живог бића, глагол означава понашање или обављање каквог посла или радњу и резултат радње, што је ређи случај.

\begin{tabular}{|l|l|l|l|}
\hline Творбени модел & Мотивна именица & Деривирани глагол* & Глаголска именица \\
\hline \multirow{5}{*}{ Ио +-исати } & Хегел & хегел-исати & хегелисање \\
\cline { 2 - 4 } & професор & професор-исати & професорисање \\
\cline { 2 - 4 } & содомија & содом-исати & содомисање \\
\hline Ио +-ионисати & секвенца & секвенц-ионисати & секвенционисање \\
\hline
\end{tabular}

30 Лексема мимикрирање обично се јавља као синоним лексеми прилагођавање (друштвеним приликама), као у примеру „zaostao u mojoj svijesti kao trajna spoznaja da sam drukčija i da mimikriranje ne pomaže" (http://arkzin.net/bastard/ugresic/kultl4.htm)

31 У РСЈ није регистрована лексема сауна. У електронским изворима (и српским и хрватским) појављује се глагол саунирати се: „Kako se saunirati? Nema strogog pravila za korištenje saune, samo preporuke.” (http://www.svijet-sauna.hr/najcesca_pitanja.html) и именица саунирање: Finske saune pružaju klasične užitke sauniranja." (http://www.halasthermal.hu/ sr_szauna) 
3.6. Суфикс -етати комбинује се са ономатопејским основама или са глаголима акустичног значења, док се са именицама комбинује само по изузетку. Комбинације са придевима нису потврђене у Клајновом регистру (2003: 333), а у нашем регистру забележен је супстантив шупљетање $е^{32}$ као другостепени дериват нелексикализованог глагола шупљетати који је мотивисан придевом щупаљ. Међутим, деривациони низ: 0 придев $\rightarrow 1$ глагол $\rightarrow 2$ глаголска именица уобичајен је у систему српског језика, а необичности наведених примера доприноси семантички садржај мотивних придева и непродуктиван творбени модел По + -етати.

\section{4. МОТИВНИ ГЛАГОЛИ СА ГЛАГОЛОМ У ТВОРБЕНОЈ ОСНОВИ}

4.1. Глаголске именице као деривати другог степена део су деривационе схеме:

0 глагол $\rightarrow 1$ глагол $\rightarrow 2$ глаголска именица.

Група првостепених глаголских деривата, са деминутивним или са итеративним значењем, па и са експресивном компонентом, мотивисаће творбу глаголских именица изведених суфиксом -юе. Суфиксацијом се ствара ефекат новог или неуобичајеног у случају глагола са деминутивним значењем (причуц̧кати $\rightarrow$ причуц̧ка-ње), или се имперфективни облик онеобичава (јау-кати $\rightarrow$ јаук-овати $\rightarrow$ јаукова-ње), или се уноси пејоративно значење (глум-атати 'извештачено глумити'- глумата-ње).

4.2. Продуктивна је творба глаголских именица од префиксираних глагола по моделу: 0 префиксирани или двоструко префиксирани глагол перфективног вида $\rightarrow 1$ глагол имперфективног вида $\rightarrow 2$ глаголска именица.

\begin{tabular}{|l|l|l|}
\hline по-детињити & подетињ-авати & подетињава-ње \\
\hline ус-комешати & ускомеш-авати & ускомешава-ње \\
\hline над-владати & надвлађ-ивати & надвлађива-ње \\
\hline о-читати & очит-авати & очитава-ње \\
\hline у-читати & учит-авати & учитава-ње \\
\hline о-бе-смислити & обесмишљ-авати & обесмишљава-ње \\
\hline на-до-снимити & надосним-авати & надосним-авање \\
\hline
\end{tabular}

32 По аналогији са дериватом лупетање. 
4.3. Није ретко образовање глаголских именица које се уклапају у деривациону схему 0 глагол $\rightarrow 1$ префиксирани глагол перфективог вида $\rightarrow 2$ глагол имперфективног вида $\rightarrow 3$ глаголска именица.

0 причати $\rightarrow 1$ нат-причати $\rightarrow 2$ натпричавати $\rightarrow 3$ натпричавање

0 орочити $\rightarrow 1$ разорочити $\rightarrow 2$ разорочавати $\rightarrow 3$ разорочавање

0 гледати $\rightarrow 1$ прогледати $\rightarrow 2$ прогледавати $\rightarrow 3$ прогледавање

0 брбљати $\rightarrow 1$ надбрбљати $\rightarrow 2$ надбрбљавати $\rightarrow 3$ надбрбљавање

0 оријентисати $\rightarrow 1$ преоријентисати $\rightarrow 2$ преоријентисавати $\rightarrow 3$ преоријентисавање

\section{5. ПЕРСПЕКТИВА ГЛАГОЛСКИХ ИМЕНИЦА}

Специфичност глаголских именица у деривационом смислу огледа се у томе да оне, за разлику од других именичких врста, не индукују даље суфиксиране деривате. Оне, међутим, имају веома важну улогу у деривацији сложеничких и полусложеничких јединица. Могу се удруживати са различитим морфолошким основама које ће се наћи на првом сложеничком месту и са мотивним речима веома различитог значења.

5.1 У Оташевићевом речнику веома је велики број сложеница са првим сложеничким делом само- (69). Однос између елемента само- и другог дела сложенице изузетно је разноврстан и тешко одредив, сматра Клајн (2002: 72). Е. Барић наводи да је већина сложеница с глаголском именицом мотивисана повратним глаголима од којих многи нису потврђени и разврстава их на три семантичка узорка:

1. сам- + -о- + И $\rightarrow$ И + самога себе (самообрана $\rightarrow$ обрана самога себе)

2. сам- + -о- + И $\rightarrow$ И + рекција глагола који је у основи именице (самосажаљење $\rightarrow$ сажаљење над самим собом)

3. сам- + -о- + И $\rightarrow$ И + по вољи самога субјекта (самоодлука $\rightarrow$ одлука по вољи самог субјекта) (Barić 1980: 64-65). Клајн додаје још један образац „,аутоматско, механичко вршење радње“ (2002: 73), који је реализован у већини забележених примера (самобацање, самопропадање, саморазлагање, самостварање, саморазлагање, самокунституисање, самоозначавање, самопречишћавање, самодовриавање, самосврставање, самопоништавање, самопотискивање и сл.). 
У семантички образац И + по вољи самога субјекта уклапају се следећи примери: самоусправљање, самоударање, самоукидање, самоограничавање, самоизјаињавање, самоистраживање, самоприказивање, самодоврмавање, самосврставање и сл.).

Прва два семантичка узорка веома су сличног концепта, и Клајн истиче да је „први само подврста другог, пошто генитив самога себе није ништа друго до рекција именице изведене из прелазног глагола (2002: 72). Овде бисмо сврстали следеће сложенице: самонавијање, самопрождирање, самопрезирање, самопосматрање, самонепознавање, самопрепознавање, самообожаване, самоиздржавање, самоуздржавање, самоисмевање, саморазумевағе, самоповређивање, самоиспитивање, самозаслепљивање, самообликовање, самозапошљавање, самопоимање и сл.

Типологија ових лексема према семантичким моделима отежана je, будући да се у концептуалним вредностима именица овога семантичкодеривационог типа често укрштају све издвојене компонете.

У Оташевићевом речникузабележени су ипримери нових сложеницатипа полу- + глаголска именица у којима формант полу- остварује значење 'непотпуно, делимично', као у примерима: полусећање, полуосећање, полуоправдање, полупризнање, полуинформисање, полуповерење, полурешавање, полуобразовање.

У истом извору забележене су и сложенице настале по следећим творбеним моделима:

\begin{tabular}{|l|l|}
\hline Ио + о + И & репомахање, буроковитлање, богопознање \\
\hline Бр + о + И & $\begin{array}{l}\text { троизбивање, тробивствовање } \\
\text { са редним бројем у основи: првооткривање }\end{array}$ \\
\hline Пр + о + И & новокомпоновање \\
\hline Прилог + И & скороизбацивање \\
\hline
\end{tabular}

Јављају се примери нових комбинација са формантима страног порекла

33 Могао би се претпоставити глагол тр-о-бивствовати, и у том случају именица тробивствовање била би првостепени сложенички дериват.

34 У сложеницама структурног типа редни број + о + И на другом месту обично се налази именица агентивног типа са људском референцијом: првобораи, првосвештеник, првобратучед.

35 Клајн наводи да су несуфиксалне сложенице на ново- малобројне и скорашњег постања (новоградња, новолигаш, новокованииа) (2002: 65). 
(префиксоидима) и глаголском именицом, еко-ламентирање ${ }^{36}$, контрабалансирање, теле-конферисање, ултра-иентрифугирање. Са израженијим обележјем неологизама су хибридни спојеви: контра-прислушкивање, параскијање, психо-истраживање, теле-образовање, као и пример визио-фонирање са новим формантом визио-.

Прави примери неологизама јесу лексеме настале срастањем вишелексемских конструкција (самогсебецитирање), или фразеолошких јединица односно идиоматизованих израза (кукутодорисање; климоглависање).

5.2. Глаголске именице су веома продуктивне у префиксалној творби, што потврђују и подаци из Оташевићевог речника. Могућа је двојака творбена интерпретација глаголских именица са префиксом у творбеној структури у зависности од тога да ли је префиксирани глагол лексикализован или није: a) као директан дериват префиксираног глагола (0 глагол $\rightarrow 1$ префиксирани глагол $\rightarrow 2$ глаголска именица, као у примеру вредновати $\rightarrow$ пре-вредновати $\rightarrow$ превреднова-ње или б) као префиксирана глаголска именица (0 глагол $\rightarrow$ 1 глаголска именица $\rightarrow$ префиксирана глаголска именица, као у примеру: иницирати $\rightarrow$ иницира-ње $\rightarrow$ де-иницирање. Поједине лексеме могу се на оба начина посматрати, нарочито уколико се префиксирани потенцијални глагол уклапа у деривациони и лексички систем. Има и примера са сложенијом деривационом схемом у којој је у последњем деривационом акту настала глаголска именица мотивисана имперфективним глаголом:

0 фарба $\rightarrow 1$ фарб-ати $\rightarrow$ ПР нат-фарбати $\rightarrow 1<$ ПР натфарб-авати $\rightarrow 2<1$ натфарбава-ње;

0 зрак $\rightarrow 1$ зрач-ити $\rightarrow$ ПР о-зрачити $\rightarrow 1<$ ПР озрач-авати $\rightarrow 2<1$ озрачава-ње.

Посведочене глаголске именице настале префиксацијом својим се значењем по правилу уклапају у постојеће семантичке обрасце карактеристичне за деривате овога структурног типа.

a) Префиксом без- означава се одсуство, непостојање (некога, нечега), а у забележеним примерима и негирање садржаја глаголске именице (безобазирање, безпостојање) те би се ови облици сматрали неологистичким

36 Формант еко- заступљен је у бројним полусложеницама: еко-парк, еко-туризам и сл. 
образовањем, будући да постоје уобичајене негиране форме: необазирағе, непостојане.

б) Забележени примери са префиксом до- (дореновирағе, донаоружавање, донауковање) имају опште значење 'завршити рању односно преостали део радње' исказане глаголском именицом.

в) Префиксали надодређење, натфарбавање остварују значење карактеристично за именичке и придевске творенице са префиксом над- 'нешто више, веће од онога што значи основна именица'.

г) Глаголске именице са префиксом пре- остварују значења типична за ову врсту префиксала: а) претерано, превелико: предимензионирање, пренаоружавање; и б) понављање радње изнова или другачије: преповезивағе, прешифровање.

д) Регистроване глаголске именице сапрефиксом пред-имајузначење које је карактеристично за глаголске префиксале 'радње која је претходила нечему': претпрограмирање, претпланирање, претфинансирање, предразумевање.

ђ) Забележене именице са префикосм раз- значе радњу супротну радњи исказаној глаголом односно глаголском именицом (разминирање) или ширење радње, повећање интензитета радње исказане глаголском именицом (раскритиковање, распросвешћивање).

е) Клајн је истакао посебну продуктивност префиксалног форманта неу смислу чисте негације с глаголским именицама. Констатује да многи од тих облика нису ни забележени у речницима, будући да су то више граматичке него лексичке појаве (2002: 185-186). И, доиста, у Оташевићевом речнику много је таквих именица (више од стотине): немицағе, неизрицање, недотицағе, непротицање, неплаћање, несећање, невладање, ненапредовање, неприпадање, нерађање, непредвиђање, некајање, непристајање, нејављање, необнављање, неиграње, непомерање, нефункиионисање и многе друге.

Исто је и са глаголским именицам са страним префиксима де-/дез. Оне се уклапају у две велике грпе префиксала са значењем: а) уклањање, одстрањивање нечега: депрограмирање, дебункерисање, дезинвестирање и б) супротност од онога што значи глаголска именица: дееволуцирање, дебрифирање, деиницирање, дехуманизовање, депроблематизовање, декласирање, дезидеологизирање. Тако и глаголске именице са префиксом ре- и значењем 
‘понављање' садржаја исказаног глаголом: ремоделирање, редизајнирање, реинаугурирање, реструктурирање, рефинансирање, реактуализирање, редимензирање, редефинисање, реемитовање, ребарбаризовање.

5.3. Продуктивни су и полусложенички спојеви: бас-музицирање, блиц-питање, видео-издање, видео-конферисање, видео-приказивање, видеоснимање, викенд-путовање, дивот-издање, диско-рвање, кич-реаговање, клик-клакање, компакт-издање, култ-издање, пилот-истраживање, попкомуницирање, порно-снимање, порно-признање, рејв-окупљање, соло-пењање, ТВ-представљање, ТВ-сучељавање, тин-идолисање, урбо-истраживање, ианкфолирање, иез-певање, иок-деловање. ${ }^{37}$

\section{6. ЗАКЉУЧАК}

Желели смо овим радом да укажемо на перспективу глаголских именица на -ње у систему српског језика на примерима забележеним у Обратном речнику нових и незабележених речи (2003) Ђорђа Оташевића. У Оташевићевом речнику наводе се само речи без значења и извора, па смо проверу употребне вредности одабраних лексема, као и значења које реализују у контексту углавном проналазили у електронским изворима различитог типа (форуми, електронска издања различитих књижевних или научних публикација, новина и сл.)

Опште је познато да је ова семантичка категорија именица високо продуктивна. Међутим, фокус истраживања у раду донекле је померен са глаголских именица на њихове мотивне глаголе и њихов семантичкодеривациони однос. Глагол у основи глаголске именице може бити са именичком или глаголском мотивацијом. Први деривациони процес одвија се по моделу: 0 именица /придев/број $\rightarrow$ глагол $\rightarrow$ глаголска именица, а други по моделу: 0 глагол $\rightarrow$ глагол $\rightarrow$ глаголска именица.

Реконструкција мотивног глагола за нерегистроване глаголске именице указује на то да је њен мотивни глагол потенцијалан, па се тако у систему ствара место за још једну јединицу. У том случају и потенцијални глагол и нерегистрована именица могу се сматрати иновативним (нпр. мејкап мејкапирати* -мејкапирање, сауна-саунирати се* -саунирање).

Нерегистрованеглаголскеименицетакођеуказују наширењесемнатичко-

37 Примери су наведени као у извору, без правописних интервенција. 
деривационих потенцијала именица или придева одређене семантичке класе у творбеној основи мотивних глагола, посебно именица са месним значењем (чаршиј-ати, иунгла-ати) или фитонима у комбинацији са суфиксом -овати (бостан-овати). У узорку су продуктивна аналошка образовања (мушковање : момковање), али се јављају и потпуно нове деривационе комбинације, као, на пример, основа збирног броја и суфикса -евати (двоје-евати). Карактеристичан је и поступак онеобичавања мотивног глагола суфиксацијом (филозоф-изовати према уобичајеном филозоф-ирати, сходно томе и филозофизовање према филозофирағе или комбиновањем домаће основе и страног суфикса (податкирати).

Потенцијал глаголских именица огледа се и у њиховој способности да учествују у даљој деривацији стварањем нових лексема. Премда не индукују даље суфиксиране деривате, оне ипак учествују, и то веома продуктивно, у слагању нових композита (репомахање, тробивствовање, скороизбацивање) и именичких префиксала (превредновање, деинициирање).

\section{ИЗВОР}

Оташевић, Ђорђе (2003). Обратни речник нових и незабележених речи. Београд: Алма.

\section{ЛИТЕРАТУРА}

Babić, Stjepan (1986). Tvorba riječi u hrvatskom književnom jeziku. Nacrt za gramatiku. Zagreb: Globus - Jugoslavenska akademija znanosti i umjetnosti.

Barić, Eugenija (198). Imeničke složenice neprefiksalne i nesufiksalne tvorbe. Zagreb: Hrvatsko filološko društvo.

Белић, Александар (1933). О грађењу глаголских именица на -ње и -ће. Наи језик. I. 262-268.

Белић, Александар (1956). Летење, седење. Наш језик. Нова серија. VII/7-8. 217-222.

Ђорђић, Петар (1932). Летење или лећење? Наш језик. I/6. 173-174.

Клајн, Иван (1998). Граматички и лексикографски статус глаголских именица од несвршених глагола. Научни састанак слависта у Вукове дане. 
27/2. 149-157.

Клајн, Иван (2002). Творба речи у савременом српском језику, Први део - слагање и префиксаиија. Београд - Нови Сад: Завод за уџбенике и наставна средства - Матица српска - Институт за српски језик САНУ.

Клајн, Иван (2003). Творба речи у савременом српском језику, Други део - суфиксаиија и конверзија. Београд - Нови Сад: Завод за уџбенике и наставна средства - Матица српска - Институт за српски језик САНУ.

Mrazović, Pavica (2009). Gramatika srpskog jezika za strance. Drugo, prerađeno i dopunjeno izdanje. Sremski Karlovci - Novi Sad: Izdavačka knjižarnica Zorana Stojanovića.

Novakov, Predrag (2009). Vendlerova klasifikacija glagola u engleskom i srpskom jeziku. Годишњак Филозофског факултета у Новом Саду. XXXIV - 1. Нови Сад. 43-50.

PCЈ: Речник српскога језика (2007). Нови Сад: Матица српска.

Стевановић, Михаило (1964). Савремени српскохрватски језик 1. Београд: Научно дело.

Терзић, Александар (1969). Структурно-семантичке одлике глаголских именица творбеног типа -ние, -ение у руском и -ње и -ће у српскохрватском језику. Анали Филолошког факултета. IX. 27-93.

Trezner, Tomislav (1970). Glagolske imenice na -nje. Jezik. 2/18. 50-54.

Gordana Štasni

\section{UNREGISTRATED GERUNDS IN SERBIAN}

\section{Summary}

In Serbian, gerunds are mostly derivated from imperfective intransitive verbs with suffix -nje and only in exceptional cases it could be derivated from perfective transitive verbs. Processuality, fragmentation, divisibility are the basic concepts for derivation of gerunds. This paper deals with the perspective of gerunds with suffix -nje in the lexical system of Serbian on the examples of the new and unregistered gerunds contained in the Obratni rečnik novih $i$ nezabeleženih reči (2003) by Đorđe Otašević. However, the focus of the research is oriented on 
motivated verbs and their semantic and derivative characteristics. In most cases gerunds show that their motivated verb also does not exist in the system, so that hypothetical verb and gerund are innovative units. Unregistered gerunds indicate the process of spreading of semanticderivational potential of some nouns and adjectives in the derivative stem of motivated verbs. The potential of gerunds is reflected in their ability to create the new lexemes, especially new compounds and prefixed words.

Key words: derivation, gerunds, suffix -nje, 